\title{
Adoption of Green IT in the university environment: systematic review of sustainability practices in educational institutions
}

\section{Adoção da TI verde no ambiente universitário: revisão sistemática de práticas de sustentabilidade em instituições educacionais}

\author{
Marcos Roque da Rosa ${ }^{1}$ \\ ${ }^{1}$ Universidade Federal da Integração Latino-Americana, Foz do Iguaçú, Paraná, Brasil. ORCID: http://orcid.org/0000-0001-7145-1069
}

Autor para correspondência/Mail to: Marcos Roque da Rosa, marcos.rosa@unila.edu.br

Recebido/Submitted: 19 de junho de 2020; Aceito/Approved: 14 de agosto de 2020

Copyright (c) 2020 Rosa. Todo o conteúdo da Revista (incluindo-se instruções, política editorial e modelos) está sob uma licença Creative Commons AtribuiçãoNãoComercial-Compartilhalgual 3.0 Não Adaptada. Ao serem publicados por esta Revista, os artigos são de livre uso em ambientes educacionais, de pesquisa e não comerciais, com atribuição de autoria obrigatória. Mais informações em http://revistas.ufpr.br/atoz/about/submissions\#tcopyrightNotice.

\begin{abstract}
Resumo
Introdução: as universidades estão preocupadas e cientes das mudanças climáticas e questões de sustentabilidade em Tecnologia da Informação (TI). TI Verde é a prática de projetar, fabricar, usar e descartar computadores, servidores e equipamentos associados com o mínimo ou nenhum impacto no meio ambiente. Objetivo: este artigo tem como objetivo examinar a implementação de casos de estudo de TI Verde no ambiente universitário a partir das práticas e resultados relatados em artigos científicos, para ter um melhor entendimento de como as universidades estão lidando com estas questões. Metodologia: para o desenvolvimento deste trabalho, foi realizada uma revisão sistemática e definido um protocolo de pesquisa baseado em publicações científicas nas bases de dados de periódicos ACM, IEEE e Scopus nos últimos dez anos. O processo foi realizado em duas etapas: busca nas bases de dados de periódicos e a análise sistemática dos artigos relacionados ao tema da pesquisa. Resultados: foram identificados nove artigos, provenientes da África, América, Ásia, Europa e Oceania, que relataram a prática da aplicação de TI Verde em universidades. Por meio dos casos estudados, discute-se como iniciar um projeto, tecnologias e dificuldades e os benefícios da implementação destas práticas. Conclusão: este estudo apresenta uma visão geral de práticas de sustentabilidade em TI, que ajudam a compreender o universo da TI Verde aplicada às universidades. A pesquisa limitou-se na análise documental qualitativa dos artigos científicos.
\end{abstract}

Palavras-chave: Computação verde; Universidade verde; Universidade sustentável; Práticas sustentáveis; Gerenciamento de Tecnologia da Informação.

\begin{abstract}
Introduction: universities are concerned and aware about climate change and sustainable issues in Information Technology (IT). Green IT is the practice of designing, manufacturing, using and disposing of computers, servers and associated equipment with minimal or no impact to the environment. Objective: the objective of this article is to research implementation of Green IT study cases in the university environment and to report the practices and results of this application. Method: to develop this work a systematic review was carried out, a research protocol was defined based on the last 10 years of scientific publications in the ACM, IEEE and Scopus periodical databases. The process was done in two stages comprehending the search in journals databases and the systematic analysis of the articles chosen that were related to the research topic. The findings of this study are case studies, on how to start a project, technologies, difficulties and benefits of the implementation. The research was limited to the qualitative documental analysis of scientific articles. Results: : As a result, nine articles were identified which reported application practices of Green IT in universities, including studies from Africa, America, Asia, Europe and Oceania. Conclusion: the study contributed with an overview about IT sustainability practices and helped to understand the universe of Green IT applied to universities.
\end{abstract}

Keywords: Green Computing; Green University; Sustainable University; Sustainable Practices; IT Management.

\section{INTRODUCTION}

The purposes of Information Technology (IT) at the university are facilitating operations, making processes faster, providing research technologies and contributing to professional training. Making IT greener can affect universities in several manners among them providing greater integration with university departments, optimizing performance of equipment, stimulating innovation, increasing student attraction and retention, and increasing the university's visibility in relation to possible business partners.

Green IT applies techniques to deal with hardware components and related equipment, such as desktops, printers, monitors and network devices, accurately and adequately, with the purpose of minimizing negative influences on the environment. This includes environmental sustainability, energy efficiency, disposal and recycling costs. It covers several areas and activities, including arrangement for eco-sustainability, environment-friendly hardware, usage of energy-saving and the renewable resource, well-designed data centers, server virtualization, waste treatment and recycling, regulation conformity, plans, goals, techniques and evaluation of results, and reduction of negative environmental issues (Murugesan, 2008). 
Green IT is constantly growing together with current technologies, and it does not only cover the study and development of systems about energy efficiency for hardware and software, but this topic is dedicated to creation of sustainable processes for commercialization of products, transportation and green building projects (Murugesan \& Gangadharan, 2012).

Green buildings require that universities reduce electricity consumption. Energy consumption by a university can be higher than that of business institutions because universities have a large number of students, administration staff, laboratories, and infrastructure to support all of these. Researchers can work hours on equipment in a laboratory and occasionally waste energy, awhile not being aware of the energy consumption or savings, that means, uniform energy saving is unrealistic for universities (Usami, Shigeta, Mashita, \& Takemura, 2013).

It is common sense that universities are a means of disseminating knowledge and practices, responsible for training future professionals who will work in companies everywhere. Universities are centers of learning and agents of change, which catalyze social and political actions, not only educating the majority of leaders, decision makers, teachers and acting in the expansion of the frontiers of knowledge, but also as important organizations that employ people and consume products and services, and perform national and international economic businesses (Dave, Gou, Prasad, \& Li, 2014).

Information technology (IT) is directly integrated with the universities and act in a range of sustainable solutions, such as the rational use of energy, the acquisition of greener equipment, reduction of consumption of natural resources and the treatment of noxious waste. The initiatives and activities that involve IT can be included in the institution's strategic planning or in a document that specifically addresses Green IT (Dave et al., 2014).

The objective of this work is a systematic review of some of case studies about Green IT implementation in the university environment and reporting the practices and results of this application, with the goal of getting better understanding about Green IT in context of universities. This study provides an overview of how this topic is being treated in the literature and discusses how to start a Green IT project at the university, which technologies to use and what are the difficulties and benefits of this implementation.

\section{METHODOLOGY}

The methodological procedure of the research involves planning, research, selection, extraction, analysis and interpretation, synthesizing and reporting.

Conducting a literature review provides information about policies and practices in any discipline. Such review process is a fundamental tool that is used to manage the diversity of knowledge and for a specific academic investigation. This would allow the researcher to map and evaluate the existing intellectual territory and to specify a research question to further develop the existing body of knowledge (Tranfield, Denyer, \& Smart, 2003).

To develop the systematic analysis of the research articles, methodological procedures were used based on the systematic literature reviews and meta-analyses, and by using evidence-based practices, systematic reviews can provide practitioners and policy makers with a reliable basis for formulating decisions and taking action by adding legitimacy and the authority of the resulting evidence (Tranfield et al., 2003).

According to Tranfield et al. (2003) the conduct of a systematic review has the following stages:

1 Review planning: identifying the need for a review, preparing a proposal and developing the protocol;

2 Conducting the review: research identification, study selection, quality assessment, data extraction and data synthesis;

3 Reporting and divulgation: generating a report and recommendations, putting evidence into practice.

In order to guide the entire process of the literature review a protocol was defined. This consists of the following items: research objective; main question; date of execution; keywords; selection criteria - definition of years of publication interval; choice of search databases; use of strings for advanced search; inclusion and exclusion criteria; definition of types of studies that will be accepted in the research; and main items to be analyzed in the articles.

The objective of the research protocol is to search case studies of Green IT implementation in the university environment while the practices and results of this application in the analyzed case studies are not known and are point question. The search covers the publication in the last 10 years, from 2009 to 2019.

Three databases of ACM, IEEE and Scopus, with large scientific recognition in the area of Computer Science, were chosen to index scientific publications. The search string was composed of keywords and the use of Boolean operators "AND"and "OR", for the refinement of results and the combination of words. Below is a table 1 with the strings and the results found in the selected periodical databases. 


\begin{tabular}{lll}
\hline Base & String & Result \\
\hline ACM & [All: "green it"] AND [[All: university] OR [All: academy] OR [All: college] & 253 documents \\
& OR [All: "educational institution"]] AND [Publication Date: (01/01/2009 & \\
& TO 12/31/2019)] & \\
IEEE & "green it"AND (university OR academy OR college OR "educational insti- & 175 documents \\
& tution") Filters Applied: 2009 - 2019 & \\
Scopus & $\begin{array}{l}\text { TITLE-ABS-KEY ( "green it"AND ( university OR academy OR college OR } \\
\text { "educational institution") ) AND PUBYEAR > 2008 AND PUBYEAR < 2020 }\end{array}$ & \\
\hline Total & & 495 documents \\
\hline
\end{tabular}

Tabela 1. Advanced search strings used in the indexing bases of journals.

Fonte: Elaborate by author (2020).

The search process at the bases resulted in a total of 495 documents, the selection process of scientific articles was carried out in a sequence of following selection criteria: 1) The document must have a direct relationship with the topic and be identified in the title, abstract or keywords; 2) The document must be classified as an article and other document formats are rejected; 3) Full text must be available for reading.

The abstracts and titles of the 495 documents, which were identified in the systematic search stage, were read and 27 duplicates discarded. After applying the selection criteria, 456 documents were rejected as they were not related to the topic and did not meet the pre-defined selection criteria. At the end of the selection process, nine articles that met the review criteria were accepted. Then, the process of extracting the articles, i.e. searching for PDF files in the bases of journals was carried out.

A systematic review was performed with aid of computer technologies to support the scientific writing of the paper. In the process of registering the protocol and selecting the articles, the desktop software StArt was used, which is a free tool developed at the Software Engineering Research Laboratory of the Federal University of São Carlos (UFSCar). This software made it possible to organize citations in the selection process, categorization and extraction of scientific articles easier. The Mendeley software was used during reading, to organize references and notes. Mendeley software is developed by Elsevier, for managing and sharing scientific references and is available in web and desktop platform. This software also allows rapid citation, integration with the word processor and quick insertion of references.

In the next section, the literature review results obtained from the procedure discussed above and the analysis of the articles will be described.

\section{RESULTS}

Green IT at the university is an environmental responsibility process that considers the environmental impact of using any resource or material, operations with less energy consumption, and proper disposal of electronic equipment, related to Green IT in the academic environment in nine selected articles, report why, how and what universities implement Green IT.

The practices and results of these studies are presented here. Two groups of studies were identified: articles that describe personal experiences of implementing Green IT, report scenarios and case studies (Table 2); and articles that measure the implementation of Green IT through questionnaires and interviews (Table 3). 


\begin{tabular}{|c|c|c|c|c|}
\hline Study & Objective & Method & Location & Results \\
\hline $\begin{array}{l}\text { Greening your com- } \\
\text { puting technology, } \\
\text { the near and far } \\
\text { perspectives (Her- } \\
\text { rick \& Ritschard, } \\
\text { 2009) }\end{array}$ & $\begin{array}{l}\text { Presenting prac- } \\
\text { tical solutions for } \\
\text { a Green IT plan, } \\
\text { aimed at IT admi- } \\
\text { nistrators on the } \\
\text { engineering college } \\
\text { campus, to reduce } \\
\text { energy use and } \\
\text { increase equipment } \\
\text { life. }\end{array}$ & $\begin{array}{l}\text { Personal experi- } \\
\text { ences, knowledge } \\
\text { about Green IT and } \\
\text { the infrastructure } \\
\text { at the Faculty. }\end{array}$ & $\begin{array}{l}\text { Faculty of Engine- } \\
\text { ering of the Colo- } \\
\text { rado State Univer- } \\
\text { sity, Colorado, USA. }\end{array}$ & $\begin{array}{l}\text { Guidance for im- } \\
\text { proving efficiency } \\
\text { in classrooms and } \\
\text { computer labs, to } \\
\text { energy-wise pur- } \\
\text { chasing instruction, } \\
\text { and software per- } \\
\text { formance controls. } \\
\text { Recommendation } \\
\text { for configuring } \\
\text { equipment, educa- } \\
\text { tion and training. }\end{array}$ \\
\hline $\begin{array}{l}\text { Implementing } \\
\text { green IT through } \\
\text { virtualisation: A } \\
\text { case study (Town- } \\
\text { send \& Mohamma- } \\
\text { dian, 2017) }\end{array}$ & $\begin{array}{l}\text { Case study analysis } \\
\text { the implementation } \\
\text { of computing virtu- } \\
\text { alization at the uni- } \\
\text { versity and how the } \\
\text { management of IT } \\
\text { systems has impro- } \\
\text { ved and what bene- } \\
\text { fits and challenges } \\
\text { have been realized. }\end{array}$ & $\begin{array}{l}\text { An analysis of the } \\
\text { existing scenario } \\
\text { with the university's } \\
\text { server environment } \\
\text { and a physical hard- } \\
\text { ware consolidation } \\
\text { project in order to } \\
\text { consolidate and } \\
\text { organize the server } \\
\text { environment. }\end{array}$ & $\begin{array}{l}\text { University of Can- } \\
\text { berra, Canberra, } \\
\text { Australia. }\end{array}$ & $\begin{array}{l}\text { Hardware standar- } \\
\text { dization, replace- } \\
\text { ment of physical } \\
\text { computing machi- } \\
\text { nes with virtual } \\
\text { servers. Energy } \\
\text { consumption has } \\
\text { been drastically } \\
\text { reduced, with a } \\
12.25 \% \text { reduction } \\
\text { over a two-year } \\
\text { period during the } \\
\text { project. }\end{array}$ \\
\hline $\begin{array}{l}\text { Framework propo- } \\
\text { sal for the environ- } \\
\text { mental impact as- } \\
\text { sessment of univer- } \\
\text { sities in the context } \\
\text { of Green IT (Mar- } \\
\text { ques, Bachega, \& Ta- } \\
\text { vares, 2019) }\end{array}$ & $\begin{array}{l}\text { Proposing a struc- } \\
\text { ture to facilitate uni- } \\
\text { versities in adopting } \\
\text { Green IT actions. }\end{array}$ & $\begin{array}{l}\text { Scientific rese- } \\
\text { arch in periodical } \\
\text { databases to } \\
\text { build knowledge, } \\
\text { simulation and } \\
\text { experimental study } \\
\text { combined with case } \\
\text { studies. }\end{array}$ & $\begin{array}{l}\text { Federal University } \\
\text { of Goiás, Campus } \\
\text { Catalão, Goiás, Bra- } \\
\text { zil. }\end{array}$ & $\begin{array}{l}\text { A framework to sup- } \\
\text { port the adoption } \\
\text { of sustainable prac- } \\
\text { tices in the univer- } \\
\text { sity context compo- } \\
\text { sed of ten steps. }\end{array}$ \\
\hline
\end{tabular}

Tabela 2. Studies with report scenarios and case studies. Fonte: Elaborate by author (2020). 


\begin{tabular}{ll}
\hline Study & Objective \\
\hline A visualization sys- & Increasing mo- \\
tem to raise awa- & tivation and the \\
reness of electricity & practice of saving \\
conservation in a & energy by analyzing \\
university building & the effect of visuali- \\
(Usami et al., 2013) & $\begin{array}{l}\text { zing a platform that } \\
\text { displays electricity } \\
\text { consumption. }\end{array}$
\end{tabular}

Drivers of green information technology in higher education in South Africa (Thomson \& Van Belle, 2014)

\section{Method}

Sensors to measure energy consumption. A platform which consists of a database, web viewer, digital signage and gadgets. Questionnaires were used to evaluate motivation.

Online survey with IT managers from South Africa.

\section{Location}

Cybermedia Center for Education and Research at Osaka University, Japan.

\section{Results}

The used platform increased the user's motivation in relation to energy saving.

South African
Higher Education
Institutions.
higher education institutions in South Africa.
Investigating the factors for the adop-

\section{Effective Green IT Strategy in a UK Higher Education Institute (AlHarbi, Kor, \& Pattinson, 2016)}

Disposal and reuse of the information technology waste: a case study in a Brazilian university (Alves \& Farina, 2018)

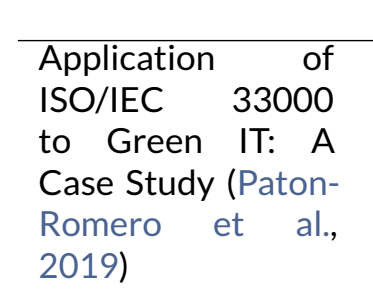

\footnotetext{
Migrating office processes to automation: An evaluation on green IT practices in a university in the Philippines (Caroro \& Hernandez, 2019)
}

The used method was an interview with two members responsible for implementation of green computing at the university. IT Strategy.

The focus is to The used method
research and analyze sustainable practices in waste administration from computer equipment in a treatment center

The purpose is
to present a case study based on an audit carried out at the university for the management of Green IT. was an interview, study of the characteristics of the materials, and theoretical references.

$\begin{array}{ll}\text { The authors perfor- } & \text { Central Unit of } \\ \text { med the collection } & \text { Valle del Cauca } \\ \text { and analysis of data } & \text { (UCEVA), Tuluá, } \\ \text { at the higher educa- } & \text { Valle del Cauca, } \\ \text { tion institution. } & \text { Colombia }\end{array}$

UK Higher Education Institution.

University of São Paulo (USP), Electronic Waste Disposal and Reuse Center, Brazil.
The adoption of Green IT is significantly affected by economic factors, general beliefs, external pressures, governmental bodies, professionals and the perceptions that they have to be ready for adopting. The study identified benefits, strategies and difficulties of the Green IT strategy at the university.

Description of electrical and electronic waste management activities and suggestions for improvement.

Tabela 3. Studies with measure the implementation through questionnaires and interviews.

Fonte: Elaborate by author (2020).

By exploring the researches, studies address how to start a project, what technologies to use, difficulties and benefits. Next, these findings which help to implementing Green IT at the university environments will be 
discussed.

\section{How to start a Green IT project at the university}

A good way to start a Green IT initiative can be inspired by Herrick e Ritschard (2009) who suggests the following activities: survey university information; define a plan for new facilities; improve the datacenter room; install automatic lighting and thermostat devices in classrooms and computer labs; use virtualization, thin clients, teleconferencing, remote management; purchase energy-saving equipments; adjust software e hardware to reduce consumption; and education and training in Green IT.

The United Nations Environment Program (UNEP) elaborated a document to assist and lead universities in planning and implementing ecological projects that aim to apply sustainable practices in the institution. The handbook provides an integrated view of the actions, sectors and units of the university in relation to the fundamentals of sustainability. The use of this document is intended to encourage universities to innovate and apply sustainable practices to improve the use of natural resources throughout the institution (Dave et al., 2014).

Strategies for implementing Green IT at the university can be guided by Marques et al. (2019), who defined a framework with ten steps: 1) to develop a Green IT program of studies; 2) identify stakeholders at the operational or strategic level; 3) define organizational support; 4) establish metrics and control indicators; 5) simulate possible future scenarios to monitor and reduce impacts; 6) propose sustainable actions; 7) apply the proposed actions; 8) report and solve difficulties; 9) monitoring; and 10) documentation.

Suggestions for improvements Green IT projects at the university can be followed by Paton-Romero et al. (2019), who recommended: promoting commitment and support from board of directors, formalization of sustainable practices, adopting a framework or standard to guide, and implementation of practices such as virtualization, recycling of electronic material, centralized printing service.

\section{Used Technologies to implementing Green IT}

Discussing about Green IT technologies, the proposed guides for improving efficiency, according by Herrick e Ritschard (2009) in classrooms and computer labs are installation of an automatic device or sensor to regulate lighting, usage of a digital thermostat controller, incorporating passive heating and cooling techniques, reduction of the overall noise level and the heat generated by the equipment, replacing CRT monitors for LCD, and part of the desktops for thin clients.

In order to money saving and reduce the use of paper, it is essential to eliminate the demand for printing and to implement electronic documentation processes, with the Digital Management System (DMS) and the usage of electronic signatures (Herrick \& Ritschard, 2009). A DMS is a class of software used to manage and storage documents electronically. The benefits of DMS are intangibles, including better collaboration with the colleagues, increased security, reduced storage space, regulatory compliance, and fast backup recovery.

Saving energy in a university is more difficult than in other kinds of businesses, because of the variety and complexity of the organization. In order to increase the user's motivation in relation to energy saving, the use of a digital signage in corridors at the university is a great strategy because this technology presents information about energy consumption for students and teachers helping the practice of saving energy (Usami et al., 2013).

The virtualization technology is the most suggested tool to implement Green IT, which is reported in the systematic reviews (AlHarbi et al., 2016; Caroro \& Hernandez, 2019; Herrick \& Ritschard, 2009; Townsend \& Mohammadian, 2017). This technology works with a software abstraction layer between the hardware and the operating system and the applications running on top of it, denominated Virtual Machine Monitor (VMM) or hypervisor that hides the physical resources of the computing system from the operating system (OS). It is possible to run more than one OS in parallel on the same hardware, because a virtual environment is recognized as being the same as that of a real environment by application programs (Sahoo, Mohapatra, \& Lath, 2010).

Another technology used to reduce energy is the hibernation in computing cited by Caroro e Hernandez (2019); Herrick e Ritschard (2009). The technology is powering down a computer while retaining its state. During this process the computer saves the contents of its random access memory (RAM) to a hard disk. After resumption, the computer will be exactly as it was before hibernation. Herrick e Ritschard (2009) report that hibernating technology is like the computer is turned off and it is a good technique to configure on all devices; after hibernation is enabled and configured, the system will automatically perform this process when the computer remains inactive for a predetermined period of time.

The software tools can be supported by Green IT projects, the systematic review presents some examples, such as GreenPrint, which finds and discards blank pages (Herrick \& Ritschard, 2009), and the ProModel software, which provides information on the scenarios devised for the computer simulation (Marques et al., 2019). The computer scenario simulations help to evaluate the environmental impact of IT, and to calculate energy consumption and $\mathrm{CO} 2$ emissions in computer labs, allowing the design of strategies for the reduction and optimization of laboratories (Marques et al., 2019). 


\section{Difficulties you can face during a Green IT project}

Green IT projects often face problems related to poor planning, lack of leadership, inefficient communication process, staff problems, low engagement, and others. Organizational culture can be difficult to change, even though benefits are presented to everyone, as people are familiar with doing things their way (Herrick \& Ritschard, 2009). A great manifestation of direction and leadership is to do what you speech, persist and motivate people for a culture changing in relation to sustainable practices (Herrick \& Ritschard, 2009). The university's chief must support sustainability actions of Green IT and incorporate these practices into the institution's strategic planning.

The study by Thomson e Van Belle (2014) showed that the adoption of Green IT in higher education institutions is significantly affected by economic factors, general beliefs of the institution, external pressures, governmental bodies, professionals and the perceptions that they have to be ready for adoption. Sometimes, higher education institutions are not feeling prepared for the adoption of Green IT and this is the main difficulty of implementation of these sustainability practices.

The analysis of existing university's server environment scenario can raise several problems for the IT team, including: the management of support contracts with different suppliers, duplicated services and systems, inconsistent operating system settings, multiple backup and recovery services, and unpredictable interactions between applications and services that share common hardware (Townsend \& Mohammadian, 2017). A physical hardware consolidation and the implementation of the virtualization is beneficial as it contributes to the hardware standardization, replacement of physical servers with virtual servers and fast creating test and development environments (Townsend \& Mohammadian, 2017).

Marques et al. (2019) report some difficulties in the implementation of Green IT, such as: low investment in sustainability actions; lack of government and community incentives for sustainability education; difficulty to identification of competences needed to well implement Green IT related measures; and installation of appropriate waste treatment systems. The authors emphasizes that reporting the difficulties is important for preventing future problems.

\section{Benefits of Adopting Green IT}

The benefits resulting from Green IT project are related to social, economical, and environmental areas. The most evident impacts on sustainability are associate with energy saving reduction of carbon emission and the expanded lifespan of equipment (AlHarbi et al., 2016; Herrick \& Ritschard, 2009; Townsend \& Mohammadian, 2017). Also the creation of centers and settings where there are also recycling programs and procedures for the reuse and disposal of computer equipment contributes to reduce existing exposure to chemical substances, damage to health and to the environment (Alves \& Farina, 2018).

The use of Green IT technologies has many benefits. The virtualization technology contributes to: energy savings through energy efficiency; reduction of acquisition costs and reduction of physical space; rapid disaster recovery and backup; creating test environments; isolation of services and applications; centralized maintenance; scalability of resources and security. The hibernation in computing helps to save energy in most desktops. Using these technologies can save money and reduce energy consumption.

By adopting sustainable projects, the university can be part of a network to share information and practices with other universities. According United Nations Environment Programme (UNEP, 2020), a Green University Network is a functional network of higher education institutions that incorporate environment, low carbon-climate resilience development strategies and sustainability aspects in their education, training, campus operations and enhanced student engagement. The UN Sustainable Development Goals related to Green University Network are: Quality Education; Sustainable Consumption and Production; Peace, Justice and Strong Institutions; and Partnerships for the Goals.

Reducing the environmental footprint of computers generally is the goal of Green IT projects. Sustainable actions attract government attention to public policies and the empowerment of people for environmental protection. Reduced environmental impact leads to less emission, less e-waste, rand fewer resources needed for manufacturing new devices.

\section{CONCLUSION}

This study aimed to search and analyze case studies about implementation of Green IT in the university environment, through a systematic review of articles in the last 10 years. Nine articles were identified that reported practices and the results of the application of Green IT in universities. The articles report case studies that can help to understand the universe of Green IT and ways of applying it at the university better. From this case studies it is conclude that an iterative process model can be used, to start a Green IT project at the university. 
Also, there are many techniques to help implementing Green IT, but generally the university starts with sustainability awareness, reduction of energy consumption and adoption of good environmental practices, server virtualization and hibernation configuration for computers are the most used technologies in Green IT projects.

It seems using virtualization technology at the university, which include initial expenditures of equipment and software to set up virtual machine servers, application license costs, and staff's training, however it offers several benefits, such as better use of the computer, return on investment, hardware standardization, and reducing energy consumption. The hibernation in computing demands operating system and hardware supports, and a set of configuration settings, wherever the particular advantage is that programs stay open so you can resume your work later, as well energy saving benefits.

Reducing the use of paper, demands to construct a printing policy and the print management software adoption that's help university staff to minimize waste. For purchase energy-saving equipments it must have to analyze the acquisition of a high-performance device and select suppliers with the green computing qualifications.

The benefit of Green IT is beyond saving money, it is a process of cultural change, principles and environmental responsibility. To achieve the goal of a sustainable university, you should reduce, reuse, and recycle. During the research, it was identified that universities have the knowledge about this topic and they have a sustainability process, at least in part, for IT resources. Universities' efforts to implement sustainable practices can inspire people in their carbon footprint, conscious consumption and responsibility to the next generations.

Future research aims to investigate how Green IT is implemented in a Latin American university located in southern Brazil, what practices and technologies are used and to propose solutions for problems and improvements. 


\section{REFERÊNCIAS}

AlHarbi, L. M., Kor, A. L., \& Pattinson, C. (2016). Effective green it strategy in a uk higher education institute. In Proceedings - 2016 ieee 14 th international conference on dependable, autonomic and secure computing, dasc 2016, 2016 ieee 14 th international conference on pervasive intelligence and computing, picom 2016, 2016 ieee 2nd international conference on big data (p. 251-256). doi: 10.1109/DASCPICom-DataCom-CyberSciTec.2016.62.

Alves, D. S., \& Farina, M. C. (2018). Disposal and reuse of the information technology waste: a case study in a brazilian university. European Business Review, 30(6), 720-734. doi: 10.1108/EBR-08-2016-0117.

Caroro, R. A., \& Hernandez, A. A. (2019). Migrating office processes to automation: An evaluation on green it practices in a university in the philippines. In 2018 ieee 10th international conference on humanoid, nanotechnology, information technology, communication and control, environment and management (p. 1-9). doi: 10.1109/HNICEM.2018.8666418.

Dave, M., Gou, Z., Prasad, D., \& Li, F. (2014). Greening universities toolkit: Transforming universities into green and sustainable campuses: A toolkit for implementers. Recuperado de http://hdl.handle.net/20.500.11822/11964.

Herrick, D. R., \& Ritschard, M. R. (2009). Greening your computing technology, the near and far perspectives. In Proceedings of the 2009 acm siguccs fall conference (p. 297303). doi: 10.1145/1629501.1629557.

Marques, C., Bachega, S. J., \& Tavares, D. M. (2019). Framework proposal for the environmental impact assessment of universities in the context of green it. Journal of Cleaner Production, 241(118346). doi: 10.1016/j.jclepro.2019.118346.

Murugesan, S. (2008). Harnessing green it: Principles and practices. International Journal of Market Research, 10(1), 24-33. doi: 10.1109/MITP.2008.10.

Murugesan, S., \& Gangadharan, G. R. (2012). Green it: An overview. In Harnessing green it. doi: 10.1002/9781118305393.ch1.

Paton-Romero, J. D., Baldassarre, M. T., Rodreguez, M., Perez-Canencio, J. G., Ojeda-Solarte, M. L., Rey-Piedrahita, A., \& Piattini, M. (2019). Application of iso/iec 33000 to green it: A case study. IEEE Access, 7, 116380-116389. doi: 10.1109/access.2019.2936451.

Sahoo, J., Mohapatra, S., \& Lath, R. (2010). Virtualization: A survey on concepts, taxonomy and associated security issues. In 2 nd international conference on computer and network technology (p. 222-226). doi: 10.1109/ICCNT.2010.49.

Thomson, S., \& Van Belle, J.-P. (2014). Drivers of green information technology in higher education in south africa. In Proceedings of the 8th european conference on information management and evaluation. (p. 234243). Recuperado de https://www.scopus.com/inward/ record. uri? eid $=2-\mathrm{s} 2.0-84942125334 \&$ partnerID $=40 \& \mathrm{md} 5=$ e193222034d70be5cefbf1087f847e33.

Townsend, T., \& Mohammadian, M. (2017). Implementing green it through virtualisation: A case study. Journal of Telecommunication, Electronic and Computer Engineering, 9(3-8), 51-56. Recuperado de https://www.scopus.com/ record/display.uri?eid $=2$-s2.0-85041857071\&origin $=$ inward\&txGid=6c0902b87c5303c39f40215e7b1cf80e.

Tranfield, D., Denyer, D., \& Smart, P. (2003). Towards a methodology for developing evidence-informed management knowledge by means of systematic review. British Journal of Management, 14(3), 207-222. doi: 10.1111/14678551.00375 .

UNEP. (2020). Green university networks. Recuperado de https://www.unenvironment.org/explore-topics/ education-environment/why-does-education-and -environment-matter/green-university.

Usami, J., Shigeta, H., Mashita, T., \& Takemura, H. (2013). A visualization system to raise awareness of electricity conservation in a university building. In Ieee green technologies conference. (p. 380-385). doi: 10.1109/GreenTech.2013.65.
Como citar este artigo (APA):

Rosa, M. R. da (2020). Adoption of Green IT in the university environment: systematic review of sustainability practices in educational institutions. AtoZ: novas práticas em informação e conhecimento, 9(2), 79 - 87. Recuperado de: http://dx.doi.org/10.5380/ atoz.v9i2.74598 